\title{
Relationship Between Jumping Ability, Agility and Sprint Performance of Elite Young Basketball Players: A Field-Test Approach
}

\section{Relação entre capacidade de salto, agilidade $e$ velocidade em jovens jogadores de Basquetebol: uma abordagem com testes de campo}

Abbas Asadi ${ }^{1}$

Abstract - The purpose of this study was to determine the relationships between sprint, agility and jump performance of elite young basketball players. Sixteen elite national level young male basketball players participated in this study. The jumping ability of each player was determined using countermovement jump (CMJ), and broad long jump (BLJ). The agility T test (TT) and Illinois agility test (IAT) were assessed to determine the agility, and 20-m sprint time was also measured to determine sprint performance. The results of Pearson Product Moment Correlation analysis indicated moderate correlation between training age and IAT $(r=-0.57 ; p=0.021)$. Strong correlations were found between CMJ and BLJ $(r=0.71 ; p=0.002)$, and between TT and IAT $(r=0.70 ; p=0.002)$. Similarly, $20-\mathrm{m}$ sprint time was strong correlated with $\mathrm{CMJ}(\mathrm{r}=-0.61 ; \mathrm{p}=0.011), \mathrm{BLJ}(\mathrm{r}=-0.76$; $\mathrm{p}=0.001)$, TT $(\mathrm{r}=0.77 ; \mathrm{p}=0.001)$, and IAT $(\mathrm{r}=0.68 ; \mathrm{p}=0.003)$. In addition, CMJ was strongly correlated with TT $(r=-0.60 ; p=0.013)$, and IAT $(r=-0.64 ; p=0.007)$, and also strong correlation between BLJ with TT $(r=-0.85 ; \mathrm{p}=0.001)$ and IAT $(r=-0.76$; $\mathrm{p}=0.001$ ). The findings of the present study indicated significant correlation between sprint and agility, jumping ability and sprint performance and between jumping ability and agility performance in basketball players. Therefore, the results suggest that sprint, agility and jumping ability share common physiological and biomechanical determinants.

Key words: Athletic performance; Muscle Strength; Physical education and training.

Resumo - Objetivou-se determinar a relação entre velocidade, agilidade e capacidade de salto em jovens jogadores de Basquetebol. Dezesseis jovens atletas de basquetebol de Elite (Iran) foram avaliados. A capacidade de salto foi avaliada por meio do teste contramovimento (Jump TestCJT) e o salto em comprimento (Long Jump - LJ). A agilidade foi avaliada por meio do Teste $T(T T)$ e do Teste de Illinois (TI). A velocidade foi avaliada por meio do teste de 20 metros. Os resultados do Coeficiente de Correlação de Pearson ( $r$ ) indicaram moderada correlação entre a idade e o TI $(r=-0,57 ; p=0,021)$. Correlaçôes de magnitude forte foram encontradas entre CJT e LJ $(r=0,71 ; p=0,002)$, o TT e TI $(r=0,70 ; p=0,002)$. As correlações com o teste de velocidade de 20 metros foram de magnitude elevada como CJT $(r=-0,61 ; p=0,011), L J(r=$ $-0,76 ; p=0,001), T T(r=0,77 ; p=0,001)$, e o TI $(r=0,68 ; p=0,003)$. Além disso, CJTfoi fortemente correlacionado com TT $(r=-0,60 ; p=0,013)$, e TI $(r=-0,64 ; p=0,007)$, e também entre o LJ com TT $(r=-0,85 ; p=0,001)$ e TI $(r=-0,76 ; p=0,001)$. Os achados desse estudo indicaram correlação entre velocidade e agilidade, capacidade de salto e velocidade e entre capacidade de salto e agilidade em jovens atletas de basquetebol. Os resultados sugerem que velocidade, agilidade e capacidade de salto apresentam determinantes fisiológicos e biomecânicos em comum.

Palavras-chave: Desempenho atlético; Educação Física e treinamento; Força muscular.
1 Roudbar Branch. Islamic Azad University. Roudbar. Iran.

Received: 20 October 2015 Accepted: 17 March 2016 


\section{INTRODUCTION}

In basketball, the ability to generate maximal strength levels in the shortest period of time (muscular power) has been considered as essential to obtain high sport performance level ${ }^{1}$. Moreover, sprint and agility are vital components for the success in basketball. High-intensity movements such as jumping (for rebound, blocks and shots), turns, dribbles, sprints, screens and low intensity activities such as walking, stopping and jogging are necessary during basketball games ${ }^{2}$. Many authors have also suggested that power, agility and sprint are important characteristics for basketball players ${ }^{1,3}$. Jump height or jumping ability is very important for a basketball player, because of the player must jump as high as possible for achieving the ball during rebound task ${ }^{4}$. Also, sprinting ability play a critical role in basketball game, because during turns the players must run as fast as possible for the offensive and defensive structures ${ }^{5}$. Agility has been considered a physiological prerequisite in basketball ${ }^{5}$, because players are frequently involved in a variety of sudden directional changes during the game in crossing the ball ${ }^{\text {. }}$.

Assessment of the physical capacities of athletes is one of the most important issues in modern sports, many test used in order that selection procedures, for screening candidates, or to monitor the efficacy of training regimes ${ }^{7}$. Although, sports scientists focus on performance assessment, there are lacks of research examining the relationships between various performance tests. With regard to a lot of performance tests in different sports, examining correlations between these tests and sport discipline such as basketball has been elusive and determining the proper test for monitoring performance status of athletes who involved in specific sport is vital.

Many authors reported a relationship between various measures of sprint and jump performance. With regard to jump performance, Barr and Nolte ${ }^{8}$ found a significant correlation between jump performance and $10 \mathrm{~m}$ sprint $(\mathrm{r}=0.66)$. Bissas and Havenetidis ${ }^{9}$ also found a relationship between jump performance and maximal running velocity $(r=0.73)$. Kale et al. ${ }^{10}$ found a significant correlation between jump height and maximum velocity as well. Squat jump power output has been correlated to $5 \mathrm{~m}$ sprint time $^{11}$ and $10 \mathrm{~m}$ running velocity ${ }^{12}$. Countermovement jump height has also been reported to correlate to acceleration from 0 to $10 \mathrm{~m}^{13}$ and 25 to $35 \mathrm{~m}$ sprint time ${ }^{14}$. The standing long jump has also been shown to significantly correlate to $10,20,30$, and $40 \mathrm{~m}$ average velocity and acceleration values ${ }^{15}$.

Very few studies, if any, have examined these various measures of jumping and sprinting ability and agility performance in basketball players. For example, Shalfawi et al. ${ }^{16}$ reported a significant correlation between CMJ and $10 \mathrm{~m}(\mathrm{r}=0.41), 20 \mathrm{~m}(\mathrm{r}=0.46)$ and $40 \mathrm{~m}(\mathrm{r}=0.74)$ sprint times in professional men (27 years old) basketball players. Chaouachi et al. ${ }^{17}$ found a significant negative correlation between agility $T$ test and 5-jump test performance $(\mathrm{r}=-0.61)$, but there were no significant correlations between agility $\mathrm{T}$ test and 5, 10, and $30 \mathrm{~m}$ sprint times in elite male (23 
years old) basketball players. In a recent correlation study by Alemdaroglu ${ }^{18}$, the author investigated the relationship between, strength, sprinting ability, agility and vertical jump performance in men ( 25 years old) basketball players and found significant correlation between countermovement jump and squat jump $(\mathrm{r}=0.80), 30 \mathrm{~m}$ sprint $(\mathrm{r}=-0.61)$, and agility $\mathrm{T}$ test $(\mathrm{r}=$ - 0.59), without any correlations between $10 \mathrm{~m}$ sprint and jumping ability and agility performance.

While previous authors investigated the relationship between sprinting ability, agility and jump performance in other athletes ${ }^{8-13}$, an insufficient number of studies have been conducted on basketball players especially young (under 20 years old) and elite (national level) male basketball players and with regard to effects of several factors such as age and training status of athletes ${ }^{19}$ on performance results, a work for determining the relationship between maximal-intensity exercise performance tests in elite and national level young male basketball players is vital and the knowledge about this aspect and age is little. In addition, previous studies used laboratory tests, but the novel approach in this study was field tests. In general, the reliability and validity of the laboratory tests are greater than field tests, but the field approach test are often more valid because of their greater specificity to sport events ${ }^{20}$. Therefore, the purpose of the study was to determine the relationship between jumping ability (countermovement jump and broad long jump), agility ( $\mathrm{T}$ test and Illinois agility test) and sprint (20-m) performance in elite young ( $<20$ years) male basketball players.

\section{METHODOLOGICAL PROCEDURES}

\section{Subjects}

Sixteen young male professional basketball players (age $19.5 \pm 0.8 \mathrm{y}$; height $180.2 \pm 7.4 \mathrm{~cm}$; body mass $72.1 \pm 10.4 \mathrm{~kg}$ and training age $5.1 \pm 1.6 \mathrm{y}$ ), who were in National level (Guilan province team, Iran), volunteered to participate in this study. All athletes were informed about the risks and benefits of participation in the study and signed informed consent forms. Inclusion criteria included (a) no history of ankle, knee or back injuries, (b) any lower extremity reconstructive surgery in the past two years or unresolved musculoskeletal disorders, and (c) not use of ergogenic aids. All procedures were approved by Islamic Azad University's Human Research Ethics Committee.

\section{Study Design}

Athletes reported to the basketball gym at 16:00. On entering the gym, height $(\mathrm{m})$, body mass $(\mathrm{kg})$, age $(\mathrm{y})$ and training age $(\mathrm{y})$ were measured for each athlete. The athletes were familiar with the testing protocols which described by certificated Strength and Conditioning coach. Each player was instructed and verbally encouraged to give a maximal effort during all tests. A standardized warm-up, consisting of jogging, dynamic stretching, and a series of increasing intensity sprints, was performed before testing. 
No static stretching exercises were allowed before any test. To determine reliability, two measurements were made in 10 athletes, 72 hours apart.

\section{Testing Methods}

Anthropometric measurements: Height was measured using a wall mounted stadiometer (Seca 222, Terre Haute, IN) recorded to the nearest $0.5 \mathrm{~cm}$. Body mass was measured to the nearest $0.1 \mathrm{~kg}$, using a digital scale (Tanita, BC-418MA, Tokyo, Japan).

Jumping ability: The countermovement jump (CMJ) was assessed using a Vertec (Power System, Knoxville, Tennessee) which fixed in basketball court. Jump height was determined using an acknowledged Vertec technique calculation ${ }^{21}$. During the jump, the athletes were instructed to use their hands while performing a downward movement followed by a maximal-effort vertical jump. All athletes were instructed to land in an upright position and to bend the knees following landing. For the broad long jump (BLJ), the athletes were required to stand with their toes behind the zero point of the tape measure prior to jumping. Each athlete initiated the jump with countermovement and arm swing. Each athlete jumped horizontally as far as possible and landed over the top of a tape measure secured to the floor. Distance was determined measuring the point at which the heel of the trial leg touched the ground. Each athlete was given three trials, and the highest score was recorded for analysis. A 30-second break between trials was allowed for recovery ${ }^{21}$.

Agility: Agility was assessed using the T-Test (TT) and Illinois Agility Test (IAT). The tests were conducted on a wooden basketball court. Agility time was recorded using a stopwatch (Joerex, ST4610-2, China). In TT the athletes were instructed to sprint from a standing starting position to a cone $10 \mathrm{~m}$ away, followed by a side shuffle left to a cone 5 $\mathrm{m}$ away. After touching the cone, the athletes side shuffled to the cone $10 \mathrm{~m}$ away and then side shuffled back to the middle cone. The test was concluded by back pedaling to the starting line. Athletes were disqualified if they failed to touch the base of any cone, crossed the one foot in front of the other, or failed to face forward for the entire test. The IAT is set up with four cones forming the agility area (10 $\mathrm{m}$ long $\times 5 \mathrm{~m}$ wide). A cone was placed at each point A) to mark the start, B and C) to mark the turn spots, and D) to mark the finish. Another four cones were placed in the center of the testing area, $3.3 \mathrm{~m}$ from each other. For all agility tests, the athlete started on the floor, face down, and begins with a random sound. The athletes must complete, as fast as possible, the agility circuit. The test score was recorded as the best time of 2 trials, to the nearest 0.01 second. A 2-minute rest period was allowed between each trial ${ }^{22}$.

$20 \mathrm{~m}$ sprint: The sprint test was performed on an indoor track basketball court. The sprint running test consisted of 2 maximal sprints of $20 \mathrm{~m}$, with a 120 -s rest period between each sprint. In $20 \mathrm{~m}$ sprint, the starting position was standardized to a still split standing position with the toe of the preferred foot forward and behind the starting line. Sprint start was 
given by a random sound, which triggers timing. On "GO" commend, the athletes run the $20 \mathrm{~m}$ track with maximal effort, as fast as possible. The timing system and procedures were same as the agility tests ${ }^{23}$.

\section{Statistical Analysis}

The mean and standard deviation values for each test were calculated for all players. The relationships between jumping ability, agility and sprint performance were analyzed using the Pearson Correlation Analysis $(r)$, with the level of statistical significance set at $p \leq 0.05$ in SPSS for Windows, version 16.0 (SPSS, Inc., Chicago, IL). The intraclass correlation coefficient (ICC) was used to determine the reliability of the measurements.

\section{RESULTS}

The results of ICC and players' performance tests are shown in Table 1 and 2 , respectively.

Table 1. The intraclass correlation coefficient (ICC) for the performance tests.

\begin{tabular}{ll}
\hline Measures & ICC \\
\hline Countermovement jump (cm) & 0.95 \\
Broad long jump (cm) & 0.99 \\
Agility T test (sec) & 0.98 \\
Illinois agility test (sec) & 0.94 \\
20-m sprint (sec) & 0.97 \\
\hline
\end{tabular}

Table 2. Basketball players' performance tests.

\begin{tabular}{lccccc}
\hline Variables & $\mathrm{n}$ & Min & Max & Mean & \pm SD \\
\hline Countermovement jump (cm) & 16 & 35 & 59 & 48.2 & \pm 7.2 \\
Broad long jump (cm) & 16 & 200 & 255 & 222.4 & \pm 18.3 \\
Agility T test (sec) & 16 & 9.9 & 13.3 & 11.7 .1 & \pm 0.9 \\
Illinois agility test (sec) & 16 & 15.5 & 18.2 & 16.8 & \pm 0.8 \\
20-m sprint (sec) & 16 & 3.25 & 3.96 & 3.5 & \pm 0.2 \\
\hline
\end{tabular}

SD: standard deviation.

The results of the Pearson Correlation Analysis indicated moderate to strong correlations between jumping ability and agility performance. Similarly, jumping ability showed moderate to strong correlations with sprint performance. There was a strong correlation between agility and sprint time performance. In addition, there were no correlations between athletes' characteristics and performance tests (except between training age and IAT, $\mathrm{r}=-0.57, \mathrm{p}=0.02)($ Table 3$)$. 
Table 3. Pearson's (r) correlations between athletes' characteristics and performance tests

\begin{tabular}{|c|c|c|c|c|c|c|c|c|}
\hline & CMJ & BLJ & TT & IAT & $20 \mathrm{~m}$ sprint & Height & Body mass & Training age \\
\hline CMJ & & $\begin{array}{c}0.71 \\
p=0.002\end{array}$ & $\begin{array}{c}-0.60 \\
p=0.01\end{array}$ & $\begin{array}{c}-0.64 \\
p=0.007\end{array}$ & $\begin{array}{c}-0.61 \\
p=0.01\end{array}$ & $\begin{array}{c}0.22 \\
\mathrm{~ns}\end{array}$ & $\begin{array}{c}0.38 \\
\mathrm{~ns}\end{array}$ & $\begin{array}{c}0.05 \\
\mathrm{~ns}\end{array}$ \\
\hline BLJ & $\begin{array}{c}0.71 \\
p=0.002\end{array}$ & & $\begin{array}{c}-0.85 \\
p=0.001\end{array}$ & $\begin{array}{c}-0.76 \\
p=0.001\end{array}$ & $\begin{array}{c}-0.76 \\
p=0.001\end{array}$ & $\begin{array}{c}0.26 \\
\mathrm{~ns}\end{array}$ & $\begin{array}{c}0.42 \\
\text { ns }\end{array}$ & $\begin{array}{c}0.35 \\
\text { ns }\end{array}$ \\
\hline TT & $\begin{array}{c}-0.60 \\
p=0.01\end{array}$ & $\begin{array}{c}-0.85 \\
p=0.001\end{array}$ & & $\begin{array}{c}0.70 \\
p=0.002\end{array}$ & $\begin{array}{c}0.77 \\
p=0.001\end{array}$ & $\begin{array}{c}0.04 \\
\text { ns }\end{array}$ & $\begin{array}{c}-0.24 \\
\mathrm{~ns}\end{array}$ & $\begin{array}{c}-0.20 \\
\mathrm{~ns}\end{array}$ \\
\hline IAT & $\begin{array}{c}-0.64 \\
p=0.007\end{array}$ & $\begin{array}{c}-0.76 \\
p=0.001\end{array}$ & $\begin{array}{c}0.70 \\
p=0.002\end{array}$ & & $\begin{array}{c}0.68 \\
p=0.003\end{array}$ & $\begin{array}{c}0.14 \\
\text { ns }\end{array}$ & $\begin{array}{c}0.02 \\
\text { ns }\end{array}$ & $\begin{array}{c}-0.57 \\
p=0.02\end{array}$ \\
\hline $20 \mathrm{~m}$ sprint & $\begin{array}{c}-0.61 \\
p=0.01\end{array}$ & $\begin{array}{c}-0.76 \\
p=0.001\end{array}$ & $\begin{array}{c}0.77 \\
p=0.001\end{array}$ & $\begin{array}{c}0.68 \\
p=0.003\end{array}$ & & $\begin{array}{c}-0.03 \\
n s\end{array}$ & $\begin{array}{c}-0.35 \\
n s\end{array}$ & $\begin{array}{c}-0.40 \\
\mathrm{~ns}\end{array}$ \\
\hline
\end{tabular}

CMJ: countermovement jump; BLJ: broad long jump; TT: T test; IAT: Illinois agility test; ns: non-significant.

\section{DISCUSSION}

The purpose of this study was to determine the relationship between jumping ability, agility and sprint performance in young male basketball players. The second purpose of the study was to determine the association between maximal-intensity performance tests with athletes' characteristics. One of the important approaches for the current study was to field tests compared to previous studies which used laboratory tests. Although, the reliability and validity of the laboratory tests are greater than field tests, the field approach tests are often more valid because of their greater specificity to sport events.

In this study, the Pearson correlation analysis indicated significant relationship between CMJ and TT $(r=-0.60), \mathrm{CMJ}$ and IAT $(\mathrm{r}=-0.64)$, BLJ and TT $(r=-0.85)$ and BLJ and IAT $(-0.76)$ in basketball players. Agility is a multifactorial physical ability which affected by strength, speed, balance, flexibility, and muscular coordination ${ }^{17}$. The findings of the present study showed moderate to strong correlations between jumping ability and agility performance of young basketball players. In this study, agility considered as performance in a basketball-specific test (i.e., TT and IAT) was significantly related to $\mathrm{CMJ}$ and BLJ performance. In accordance with the present study, Koklu et al. ${ }^{24}$ reported significant correlations between CMJ and zigzag agility test with $(\mathrm{r}=-0.45)$ and without $(\mathrm{r}=-0.76)$ the ball in soccer players. Chaouachi et al. ${ }^{17}$ found a significant negative correlation between TT and jump test performance $(r=-0.61)$ in elite male $(23$ years old) basketball players. In a recent correlation study by Alemdaroglu ${ }^{18}$, the author reported significant correlation between CMJ and TT $(r=-0.59)$ in professional men ( 25 years old) basketball players. Based on the current findings and previous reports, it could, however, be speculated that the physiological profile of agility and jump performance is similar in basketball players and the strength and conditioning coaches in the field of basketball can use one of these tests to determine the status of athletes.

The results from the present study indicated significant relationship between CMJ and $20 \mathrm{~m}(\mathrm{r}=-0.61)$, and between BLJ and $20 \mathrm{~m}(-0.76)$ sprint performance in basketball players. In accordance with these findings, 
Barr and Nolte ${ }^{8}$ found a significant correlation between jump performance and $10 \mathrm{~m}(\mathrm{r}=0.66)$. Bissas and Havenetidis ${ }^{9}$ also found a relationship between jump performance and maximal running velocity $(r=0.73)$. Kale et al. ${ }^{10}$ found a significant correlation between jump height and maximum velocity as well. Countermovement jump height has also been reported to correlate to acceleration from 0 to $10 \mathrm{~m} 16$ and 25 to $35 \mathrm{~m}$ sprint time ${ }^{14}$. The standing long jump has also been shown to significantly correlate to 10 , 20,30 , and $40 \mathrm{~m}$ average velocity and acceleration values ${ }^{15}$. In basketball players, Shalfawi et al. ${ }^{16}$ reported a significant correlation between CMJ and $10 \mathrm{~m}(\mathrm{r}=0.41), 20 \mathrm{~m}(\mathrm{r}=0.46)$ and $40 \mathrm{~m}(\mathrm{r}=0.74)$ sprint times in professional men (27 years old) basketball players. Chaouachi et al. ${ }^{17}$ also found significant correlations between $30 \mathrm{~m}$ sprint time and CMJ in elite male (23 years old) basketball players. In a recent correlation study by Alemdaroglu ${ }^{18}$, the author investigated the relationship between sprinting ability and jump performance in men ( 25 years old) basketball players and found significant correlation between CMJ and $30 \mathrm{~m}$ sprint $(\mathrm{r}=-0.61)$ performance. The explanation for the association between jumping ability (i.e., CMJ and BLJ) and measures of sprint performance (i.e., $20 \mathrm{~m}$ ) could be due to needs to maximal effort action at the start of the sprint. As the athletes starts to sprint, the body accelerates forward to a maximal velocity. This velocity is determined by the force that muscle can generate against the ground, multiplied by the time during which the forces are applied which in turn equals power. As the athletes accelerate towards top speed through $20 \mathrm{~m}$, the foot contact time on the ground becomes relatively short, which makes force and leg strength more important than power in this phase ${ }^{25,26}$.

In this study, the Pearson correlation analysis indicated significant relationship between TT and $20 \mathrm{~m}(\mathrm{r}=0.77)$, and IAT and $20 \mathrm{~m}(\mathrm{r}=0.68)$ in basketball players. The findings of the present study showed moderate to strong correlations between agility and sprint performance of young basketball players. In agreement with the results of the current study, Alemdaroglu ${ }^{18}$ reported positive relationship between $30 \mathrm{~m}$ sprint and TT $(\mathrm{r}=0.50)$ in Turkish professional men (25 years old) basketball players. The relationship between sprint and agility performance have been examined by very few studies ${ }^{14,27,28}$. Moderate correlation was reported between agility TT and sprint performance in a group of college-aged women ${ }^{28}$. In contrast, Little and Williams ${ }^{27}$ reported a weak but significant correlation between $10 \mathrm{~m}$ sprint and zigzag agility test in a group of professional male soccer players. In contrast, Buttifant et al. ${ }^{29}$ reported no significant correlations between $20 \mathrm{~m}$ sprint and agility. In basketball athletes, Chaouachi et al. ${ }^{17}$ did not find significant correlations between agility TT and 5,10 , and $30 \mathrm{~m}$ sprint times in elite male ( 23 years old). The reasons for discrepancy between studies could be due to using different agility tests ${ }^{17,29}$ and differences between participants in the studies because of Chamari et al. ${ }^{30}$ suggests a potential effect of age or experience when examining the relationship between these maximal-intensity exercise performance tests. 
This study did not find correlations between maximal-intensity performance tests and the status of athletes. Only the Pearson correlation analysis showed significant relationship between IAT and training age $(r=-0.57)$ in basketball players and there were no significant correlations between body mass, height and performance tests. Little is known, in literature, about the relationship between athletes' characteristics and performance tests in basketball players and therefore discussion about this subject is difficult. In accordance with the results of this study, Chaouachi et al. ${ }^{17}$ did not find correlations between height, body fat and sprint performance, but they addressed positive association between body mass and agility TT $(r=0.58)$ in Tunisian men basketball players. The negative correlation between IAT and training age could be the positively transfer of basketball task during games and competitions to IAT. Based on the specificity of basketball movements, several change of direction, zigzag drill and dribble movements would be occur and resulting agility adaptations.

In light of the present study, findings on jumping ability, agility and sprint should be regarded as a major physiological ability in young male elite basketball players. Short-term, maximal-intensity exercise performance should be considered as a basketball-related activity. Because of the association between jump performance and agility and sprint times, jump exercises should be considered in basketball conditioning. As a result of the nature of basketball tasks, the jump exercise and short sprint event and agility may be used emphasizing the maximal force mobilization. The result of the study is that performances in a variety of field tests were correlated with each other in a group of basketball players. It can be state that either the tests assess similar attributes or performance on one test is able to predict performance on another and athletes with greater training age is agile than others.

\section{CONCLUSION}

In summary, the findings of the present study indicated a significant correlation between jumping ability and agility performance and sprint time in young male basketball players. One of the possible reasons for these findings could be that all maximal-intensity exercise performance tests include dynamic movements requiring high muscle power. Since, all maximal-intensity exercise performance tests have same energy systems; it seems that ATP-PC pathway play a critical role for basketball players and therefore suggests that jumping ability, agility, and sprint performance share common physiological and biomechanical determinants.

\section{REFERENCES}

1. Klinzing JE. Training for improved jumping ability of basketball players. Nat Strength Cond Ass J 1991; 13(3): 27-32.

2. Drinkwater E, Pyne D, McKenna M. Design and interpretation of anthropometric and fitness testing of basketball players. Sports Med 2008; 38(7): 565-78 
3. Latin RW, Berg K, Baechle T. Physical and performance characteristics of NCAA Division I male basketball players. J Strength Cond Res 1994; 8(3): 214-8.

4. Abdelkrim N, Fazaa S, Ati J. Time-motion analysis and physiological data of elite under-19-year-old basketball players during competition. Br J Sports Med 2007; 41(2): 69-75.

5. Erculj F, Blas M, Bracic M. Physical demands on young elite European female basketball players with special reference to speed, agility, explosive strength, and take-off power. J Strength Cond Res 2010; 24(11): 2970-8.

6. McInnes, SE, Carlson JS, Jones CJ, McKenna MJ. The physiological load imposed upon basketball players during competition. J Sports Sci 1995; 13(5): 387-97.

7. Norkowski H. Anaerobic power of handball players representing various sport levels. J Hum Kinetics 2002; 7(1): 43-50.

8. Barr MJ, Nolte VW. Which measure of drop jump performance best predicts sprinting speed? J Strength Cond Res 2011; 25(7): 1976-82.

9. Bissas AI, Havenetidis K. The use of various strength-power tests as predictors of sprint running performance. J Sports Med Phys Fitness 2008; 48(1): 49-54.

10. Kale M, Asci A, Bayrak C, Acikada C. Relationships among jumping performances and sprint parameters during maximum speed phase in sprinters. J Strength Cond Res 2009; 23(8): 2272-9.

11. Cronin JB, Hansen KT. Strength and power predictors of sports speed. J Strength Cond Res 2005; 19(2): 349-57.

12. Smirniotou A, Katsikas C, Paradisis G, Argeitaki P, Zacharogiannis E, Tziortzis S. Strength-power parameters as predictors of sprinting performance. J Sports Med Phys Fitness 2008; 48(4): 447-54.

13. Young W, Cormack S, Crichton M. Which jump variables should be used to assess explosive leg muscle function? Int J Sports Physiol Perform 2011; 6(1): 51-7.

14. Vescovi JD, McGuigan MR. Relationships between sprinting, agility, and jump ability in female athletes. J Sports Sci 2008; 26(1): 97-107.

15. Brechue WF, Mayhew JL, Piper FC. Characteristics of sprint performance in college football players. J Strength Cond Res 2010; 24(5): 1169-78.

16. Shalfawi SAI, Sabbah A, Kailani G, Tonnessen E, Enoksen E. The relationship between running speed and measure of vertical jump in professional basketball players: a field-test approach. J Strength Cond Res 2011; 25(11): 3088-92.

17. Chaouachi A, Brughelli M, Chamari K, Levin GT, Ben Abdelkrim N, Laurencelle L, Castagna, C. Lower limb maximal dynamic strength and agility determinants in elite basketball players. J Strength Cond Res 2009; 23(5): 1570-7.

18. Alemdaroglu U. The relationship between muscle strength, anaerobic performance, agility, sprint ability and vertical jump performance in professional basketball players. J Hum Kinetics 2012; 31(2): 99-106.

19. Salaj S, Markovic G. Specificity of jumping, sprinting, and quick change-ofdirection motor abilities. J Strength Cond Res 2011; 25(5): 1249-55.

20. MacDougall D, Sale D. The physiology of training for high performance. Oxford University press, 2014.

21. Arazi H, Coetzee B, Asadi A. Comparative effect of land and aquatic based plyometric training on the jumping ability and agility of young basketball players. South African J Res Sport Phys Edu Rec 2012; 34(1): 1-14.

22. Miller MG, Herniman TJ, Ricard MD, Cheatham CC, Michael TJ. The effects of a 6-week plyometric training program on agility. J Sport Sci Med 2006; 5(3): 459-65.

23. Rimmer E, Sleivert G. Effects of a plyometric intervention program on sprint performance. J Strength Cond Res 2000; 14(3): 295-301.

24. Koklu Y, Alemdaroglu U, Ozkan A, Koz M, Ersoz G. The relationship between sprint ability, agility and vertical jump performance in young soccer players. Sci Sport 2015; 30(1): 1-5.

25. Weyand PG, Sternlight DB, Bellizzi MJ, Wright S. Faster top running speeds are achieved with greater ground forces not more rapid leg movements. J Appl Physiol 2000; 89(5): 1991-9. 
26. Mero A, Luhtanen P, Komi PV. A biomechanical study of the sprint start. Scan J Sports Sci 1983; 5(1): 20-8.

27. Little T, Williams AG. Specificity of acceleration, maximum speed, and agility in professional soccer players. J Strength Cond Res 2005; 19(1): 76-8.

28. Paoule K, Madole K, Garhammer J, Lacourse M, Rozenek R. Reliability and validity of the t-test as a measure of agility, leg power, and leg speed in college-aged men and women. J Strength Cond Res 2000; 14(4): 443-50.

29. Buttifant D, Graham K, Cross K. Agility and speed in soccer players are two different performance parameters. In: Spinks W, Reilly T, Murphy A, editors. Proceedings of science and football IV. London: Routledge, 2002.

30. Chamari K, Hachana Y, Ahmed YB, Galy O, Sghaier F, Chatard JC. Field and laboratory testing in young elite soccer players. Br J Sports Med 2004; 38(2): 191-6.

\section{CORRESPONDING AUTHOR}

Abbas Asadi

Guilan. Roudbar. Imam Khomeini

Street.

Islamic Azad University, Iran

P0 Box 44615-1146.

E-mail: abbas_asadi1175@yahoo.

com 